\title{
Rodent adrenocortical cells display high affinity binding sites and proteins for inhibin A, and express components required for autocrine signalling by activins and bone morphogenetic proteins
}

\author{
Paul G Farnworth, Yao Wang, Pauline Leembruggen, \\ Guck T Ooi, Craig Harrison, David M Robertson \\ and Jock K Findlay \\ Prince Henry's Institute of Medical Research, PO Box 5152, Clayton, 3168 Victoria, Australia \\ (Requests for offprints should be addressed to P G Farnworth; Email: paul.farnworth@princehenrys.org)
}

\begin{abstract}
Inhibins are expressed in the adrenal cortex, but little is known of their binding or role in the adrenal. The aims of the present study were, first, to establish whether a mouse adrenocortical (AC) cell line expresses inhibins/activins and bone morphogenetic proteins (BMP), along with proteins required for inhibin to antagonise activin and BMP actions and, secondly, to characterise and compare inhibin binding sites and proteins in the rat adrenal gland and AC cells. AC cells were found to: (1) express mRNA for multiple BMPs (BMP-2, -3, -4, -6, -8a), growth/ differentiation factors (GDF-1, -3, -5, -9), Lefty A and B, and the inhibin $\alpha, \beta_{\mathrm{A}}$ and $\beta_{\mathrm{B}}$ subunits (2) secrete inhibin $\mathrm{A}$ and inhibin $\mathrm{B}$ and (3) express mRNA encoding the inhibin co-receptor, betaglycan, along with activin and BMP type I (ALK2-7) and type II (ActRII, ActRIIB, BMPRII) receptors, and binding proteins (follistatin, BAMBI, gremlin). When applied to sections of rat adrenal glands, $\left[{ }^{125} \mathrm{I}\right]$ inhibin A specifically bound to cells of the adrenal cortex, mainly in the zona reticularis. Scatchard analyses of in vitro $\left[{ }^{125} \mathrm{I}\right]$ inhibin A binding to dispersed rat adrenal cells and AC cells revealed sites of high affinity $\left(\mathrm{K}_{\mathrm{d}}(1)\right.$ of 0.18 and $0.15 \mathrm{nM}$, respectively) and low affinity $\left(\mathrm{K}_{\mathrm{d}}(2)\right.$ of 2.6 and $1.3 \mathrm{nM}$, respectively. Competition for
\end{abstract}

$\left[{ }^{125} \mathrm{I}\right]$ inhibin A binding by activin A or B $(30 \mathrm{nM})$ was negligible, whereas BMP-2, -6 and -7 competed for between 21 and 33\% of specific inhibin A binding $\left(\mathrm{IC}_{50}\right.$ between 0.2 and $0.3 \mathrm{nM}$ ). Inhibin $B$ crossreaction with inhibin A binding sites was $<8 \%$. Multiple binding protein complexes (molecular weight ranging from 35 to $>220 \mathrm{kDa}$ ) were affinity labelled by $\left[{ }^{125} \mathrm{I}\right]$ inhibin $\mathrm{A}$ on both the primary rat adrenal and AC cells. The species of $>220 \mathrm{kDa}$ were shown by immunoprecipitation to include betaglycan, the species of $105 \mathrm{kDa}$ is consistent in size with type II receptors for activin/BMP, and that of $62 \mathrm{kDa}$ co-migrates with the inhibin-follistatin complex.

In summary, the results show that inhibin $\mathrm{A}$ binds selectively and with both high and low affinity to AC cells via multiple binding proteins, including a single betaglycan-like species. The results support the role of glycosylated betaglycan in the high affinity binding of inhibin A, but provide consistent evidence from two independent sources of adrenal cells that inhibin A interacts with several membrane proteins in addition to those currently understood to mediate the anti-activin/BMP actions of inhibin.

Journal of Endocrinology (2006) 188, 451-465

\section{Introduction}

Inhibins and activins are members of the transforming growth factor- $\beta$ (TGF- $\beta$ ) superfamily of pleiotropic growth and differentiation factors that includes bone morphogenetic proteins (BMP) (Piek et al. 1999, Chang et al. 2002). Inhibin A and inhibin B provide endocrine negative feedback from the gonads to the pituitary gonadotrophs, but local autocrine/paracrine actions of inhibins are also evident in tissues that synthesise and secrete them (Hsueh et al. 1987, Vale et al. 1988, Drummond et al. 2004,
O’Connor \& De Kretser 2004). Disulphide-linked dimers of inhibin $\beta$ subunits form activins, the actions of which are opposed by inhibins in some cell types, most notably the pituitary gonadotroph, but not others (Vale et al. 1988).

TGF- $\beta$ superfamily members such as activins initiate signalling by uniting a constitutively active serine/ threonine kinase type II receptor (e.g. ActRII or ActRIIB in the case of activins) with a dormant serine/threonine kinase type I receptor (e.g. ActRIB or ALK7 in the case of activins) so that it transphosphorylates and is thereby 
activated (Piek et al. 1999). Downstream signalling is mediated by type I receptor-activated Smads in combination with Smad4. Additional signalling may involve recruitment of ERK1/2, p38 MAP kinase, and phosphatidylinositol 3'-kinase/Akt (Cocolakis et al. 2001, Dupont et al. 2003). In contrast, inhibin signalling is less well understood. Although inhibin A binds with both high affinity $\left(\mathrm{K}_{\mathrm{d}}(1)=0 \cdot 1-0 \cdot 3 \mathrm{nM}\right)$ and low affinity $\left(\mathrm{K}_{\mathrm{d}}(2)=2\right.$ $5 \mathrm{nM}$ ) to cells from natural sources, including pituitary cells (Hertan et al. 1999, Farnworth et al. 2001, Harrison et al. 2001), no direct inhibin signalling has been demonstrated. Instead, it has been shown by over-expressing the TGF- $\beta$ type III co-receptor, betaglycan, in model cell systems where inhibin promotes the formation of high affinity ternary complexes involving betaglycan, inhibin, and type II receptors for activin and BMP (ActRII/IIB or BMPRII)(Lewis et al. 2000, Chapman et al. 2002, Wiater $\&$ Vale 2003). This results in the abolition of activin and BMP signalling by a dominant negative mechanism. In the absence of betaglycan, inhibin interacts directly with ActRII/IIB (Martens et al. 1997, Gray et al. 2000, Lewis et al. 2000), but not with BMPRII (Wiater \& Vale 2003). Inhibin also interacts with low affinity with follistatin (Shimonaka et al. 1991, Schneyer et al. 1994), a secreted glycoprotein better known for binding activin and BMP and neutralizing their actions (Iemura et al. 1998, Hashimoto et al. 2000). The short form of follistatin, follistatin-288, interacts with heparan sulphate proteoglycans on the cell surface where it binds activin (Sugino et al. 1993), but any physiological role for follistatin in inhibin binding is yet to be clarified.

Early studies identified the adrenal gland as a site of inhibin $\alpha$ and $\beta_{\mathrm{A}}$ subunit expression (Crawford et al. 1987, Meunier et al. 1988), and of inhibin accumulation after the intravenous injection of $\left[{ }^{125} \mathrm{I}\right]$ inhibin $\mathrm{A}$ into mice (Woodruff et al. 1993). The adrenal is also a site of action for both activin and BMP (Spencer et al. 1999, Beuschlein et al. 2003, Suzuki et al. 2004). We wished to test the hypotheses that the expression of known inhibin binding proteins is the basis for adrenal gland binding of inhibin, and also that inhibin is potentially a paracrine/autocrine antagonist of activin and BMP actions in the adrenal. Determination of where and how inhibin binds in the adrenal gland are important steps in identifying its local actions. Therefore, the aims of the present study were to characterise and compare inhibin binding sites and proteins in the rat adrenal gland and a mouse adrenocortical (AC) cell line, and to demonstrate that the AC cells express the requisite ligands and associated binding/ signalling proteins, that could allow antagonism of locally produced activin and BMP by inhibin to occur. The results suggest that a common set of proteins bind inhibin to rodent AC cells. The AC cells also express inhibin/ activin subunits, several BMPs, and their respective binding and signalling molecules, including betaglycan, and secrete both inhibins. However, AC cells from both sources express several inhibin binding proteins that are not accounted for in the current model of inhibin action.

\section{Materials and Methods}

\section{Materials}

Adult male and female rats obtained from Central Animal House, Monash University (Clayton, Victoria, Australia) were maintained under standard conditions, with free access to food and water. The studies were performed in accordance with the Australian Code of Practice for the Care and Use of Animals for Scientific Purposes, and procedures were approved by the Monash Medical Centre Animal Experimentation Ethics Committee. The AC cell line is derived from the $\mathrm{C} \alpha-1$ cell line, generously provided by Drs Ilpo Huhtaniemi and Nafis Rahman (Institute of Reproductive and Developmental Biology, Imperial College London, UK and Department of Physiology, University of Turku, Finland; Kananen et al. 1996), but does not display its reported proliferative responses to activin and inhibin (P G Farnworth, P Leembruggen and Y Wang, unpublished observations).

Cell culture reagents and fetal bovine serum (FBS) were obtained from Trace Biosciences (Castle Hill, New South Wales, Australia), antibiotics (final concentrations of $100 \mathrm{U} / \mathrm{ml}$ penicillin, $100 \mu \mathrm{g} / \mathrm{ml}$ streptomycin, $250 \mathrm{ng} / \mathrm{ml}$ fungizone) were from Commonwealth Serum Laboratories (Parkville, Victoria, Australia), insulin was from Commonwealth Serum Laboratories-Novo (North Rocks, New South Wales, Australia), and other protein supplements, protease inhibitors, octyl $\beta-\mathrm{D}$ glucopyranoside, and recombinant human inhibin $\mathrm{B}$ were obtained from Sigma Chemical Co. Recombinant human $31 \mathrm{kDa}$ inhibin $\mathrm{A}$ and $25 \mathrm{kDa}$ activin $\mathrm{A}$ (obtained in impure form from Biotech Australia, Roseville, NSW, Australia) was stored at $-70{ }^{\circ} \mathrm{C}$ following purification in $0 \cdot 1 \%$ trifluoroacetic acid/acetonitrile (Harrison et al. 2001). Purified recombinant human follistatin-288 was provided by Biotech Australia. Activin B, BMP-2, -6 and -7 , additional activin $\mathrm{A}$, and antisera against human betaglycan, ActRII, and BMPRII were obtained from R\&D Systems (Minneapolis, MN, USA), and additional BMP-2 was from Research Diagnostics Inc. (Concord, MA, USA). Ultraspec for RNA extraction was from Fisher Biotec Australia (West Perth, WA, Australia). DNA-free was from Ambion Inc. (Austin, TX, USA). Protein G-agarose, Primer $\mathrm{p}(\mathrm{dT})_{15}$, Expand Reverse Transcription, FastStart DNA Master SYBR Green I and LightCycler capillaries were from Roche Diagnostics Australia. $\mathrm{Na}^{125} \mathrm{I}$ was a product of MP Biomedicals, Inc. (Irvine, CA, USA), bis-sulfosuccinimidyl suberate $\left(\mathrm{BS}^{3}\right)$ was from Pierce Biotechnology, Inc. (Rockford, IL, USA), and $\left[\alpha_{-}{ }^{32} \mathrm{P}\right]-$ dCTP (3000 Ci/mmol), NAP-5 and PD-10 columns, and Sephadex G-100 were from Amersham Biosciences. 


\section{Culture of rat and mouse adrenal cells}

Adult (60-90 day-old) rats were killed, and primary cultures of adrenal cells were prepared by trypsin/ deoxyribonuclease digestion of the diced tissue from 20-60 whole glands using procedures previously applied for preparing rat pituitary cell cultures (Farnworth et al. 1988). Primary adrenal cells were suspended in culture medium, consisting of a 1:1 (vol:vol) mixture of Dulbecco's Modified Eagle's Medium and Ham's F12 Medium (DMEM:F12) buffered with bicarbonate, and containing antibiotics, nonessential amino acids for MEM, and supplementary glutamine $(2 \mathrm{mM})$, and supplemented with $10 \%$ FBS for the pre-incubation of cultures. AC cells (passage \#40-80) were maintained in culture medium containing 10\% FBS, and passaged 1:20 on a weekly basis. $\mathrm{AC}$ and primary adrenal cells were initially plated in serum-containing medium that, after 1 day of culture cells were transfered to serum-free medium, which was prepared by diluting culture medium 9:1 with a chemically defined artificial serum (AS) composed of Dulbecco's phosphate buffered saline (DPBS) with added $\mathrm{CaCl}_{2}$ (1.3 mM), $\mathrm{MgCl}_{2}(0.5 \mathrm{mM})$ and fatty acid-free BSA $(60 \mathrm{~g} / 1$; final concentration of $0 \cdot 6 \%)$, after which the medium was supplemented with transferrin $(1.0 \mathrm{mg} / \mathrm{l})$, and insulin $(0.5 \mathrm{mg} / \mathrm{l})$. All adrenal cell cultures prepared as described above were routinely maintained at $37^{\circ} \mathrm{C}$ in a humidified atmosphere of 5\% CO2 in air.

\section{Radioligand binding assays}

Inhibin A $(5 \mu \mathrm{g})$ was iodinated by a previously described lactoperoxidase method to a specific activity of approximately $120 \mu \mathrm{Ci} / \mu \mathrm{g}$ (Hertan et al. 1999). Binding assays were conducted on day 2 of culture at room temperature $\left(25^{\circ} \mathrm{C}\right)$, as previously described (Farnworth et al. 2001, Harrison et al. 2001). For saturation binding studies, cells were incubated with various concentrations of radioiodinated inhibin, with or without a 50-fold excess of unlabelled inhibin.

For determination of $\left[{ }^{125} \mathrm{I}\right]$ inhibin $\mathrm{A}$ binding to rat adrenal in situ, $7 \mu \mathrm{m}$ cryostat sections of whole adrenal glands frozen in OCT compound were transferred to glass microscope slides that had been coated with poly-L-lysine. Thawed sections were blocked overnight with binding buffer containing 1\% dog serum albumin, washed twice with assay buffer, then incubated with $\left[{ }^{125} \mathrm{I}\right]$ inhibin $\mathrm{A}$ (approximately $250 \mathrm{pM}$ ) in the absence or presence of unlabelled inhibin A $(20 \mathrm{nM})$ for $1.5 \mathrm{~h}$ at $37^{\circ} \mathrm{C}$ in a humidified container. Tissue sections were then thoroughly washed with ice-cold DPBS, air dried, and analysed by exposure of Kodak MR x-ray film for 7 days.

Activin A $(1 \mu \mathrm{g})$ was iodinated by a previously described chloramine $T$ method (Buzzard et al. 2003). For $\left[{ }^{125} \mathrm{I}\right]$ activin binding and affinity labelling studies, monolayers of $1 \times 10^{6}$ AC cells per well in 6-well cluster plates were incubated with $\sim 90000$ c.p.m. $\left[{ }^{125} \mathrm{I}\right]$ activin/0.60 ml/well (corresponding to a final concentration of $120-200 \mathrm{pM}$ ) for $2 \mathrm{~h}$ at $25^{\circ} \mathrm{C}$ with gentle agitation in the presence or absence of unlabelled inhibin A or activin A (20 nM final concentration).

\section{Chemical crosslinking and immunoprecipitation}

Affinity labelling of inhibin binding proteins on the $\mathrm{AC}$ cells employed the synthetic, bifunctional crosslinking agent, $\mathrm{BS}^{3}(0 \cdot 25 \mathrm{mM}$ final concentration), as previously described (Harrison et al. 2001). For analysis of AC cell membrane proteins, affinity labelled monolayers from 4-6 dishes (each containing $5 \times 10^{6}$ cells) were collected by scraping and pooled, washed 4 times in $10 \mathrm{ml}$ ice-cold crosslinking buffer $(50 \mathrm{mM}$ HEPES, $\mathrm{pH} 7 \cdot 5$, containing $130 \mathrm{mM} \mathrm{NaCl}, 5 \mathrm{mM} \mathrm{KCl}, 5 \mathrm{mM} \mathrm{MgSO}, 1.2 \mathrm{mM}$ $\mathrm{CaCl}_{2}$ and protease inhibitors), then homogenised in $2 \mathrm{ml}$ quench buffer $(80 \mathrm{mM}$ Tris, $30 \mathrm{mM} \mathrm{NaCl}, \mathrm{pH} 7 \cdot 4)$ containing PMSF (3 mM), EDTA (4 mM) and $0 \cdot 25 \%$ sucrose on ice using a Waring blender. After removal of nuclei and debris by a low speed spin $\left(160 \mathrm{~g}, 5 \mathrm{~min}, 4^{\circ} \mathrm{C}\right)$, the membrane fraction was collected by a high speed spin (30 $000 \mathrm{~g}$ for $60 \mathrm{~min}$ ), and dissolved in $0 \cdot 1-0 \cdot 25 \mathrm{ml}$ lysis buffer. After removal of undissolved material by centrifugation, membrane lysates were analysed as for whole cell lysates.

For the analysis of betaglycan-like species, aliquots of clarified lysates from whole cells $(50 \mu \mathrm{l})$ or membranes $(20 \mu \mathrm{l})$ were diluted with $0.20 \mathrm{ml}$ quench buffer, then immunoprecipitated with $10 \mu \mathrm{g} / \mathrm{ml}$ affinity purified polyclonal antiserum against human betaglycan, as previously described (Harrison et al. 2001).

Affinity labelled complexes in lysates and immunoprecipitates were separated using non-reducing $7 \cdot 5 \%$ SDS-PAGE. Dried gels were analysed by autoradiography after exposure of Kodak MS films for 1-28 days using BioMax TranScreen-HE intensifying screens (Eastman Kodak). The molecular masses of the separated complexes and polypeptides, respectively, were calculated according to their Rf values run against molecular weight standards (Bio-Rad Laboratories).

\section{RNA extraction and analysis}

Adrenal cell monolayers were dissolved in $1 \mathrm{ml}$ UltraSpec, extracted total RNA was subsequently treated with DNAfree, then aliquots $(0.5 \mu \mathrm{g})$ were run on $1.2 \%$ agarose gels and stained with ethidium bromide to check RNA integrity, and to allow 18S RNA contents to be estimated by densitometry. Profiling of TGF- $\beta$ superfamily-related gene expression by AC cells was achieved with mouse GE SuperArray filters (GEArray Series Q; SuperArray Bioscience Corp, MD, USA) consisting of 96 mouse target genes. Total RNA ( $4 \mu \mathrm{g}$ ) was reverse-transcribed, and cDNA probes were synthesised according to the method suggested by the manufacturer. After the 30-cycle 
Table 1 Oligonucleotide primer sequences used to amplify mouse activin and BMP receptors, betaglycan, and follistatin mRNAs. The position of the $5^{\prime}$-sense and antisense nucleotide of each primer within the sequence is shown in parentheses

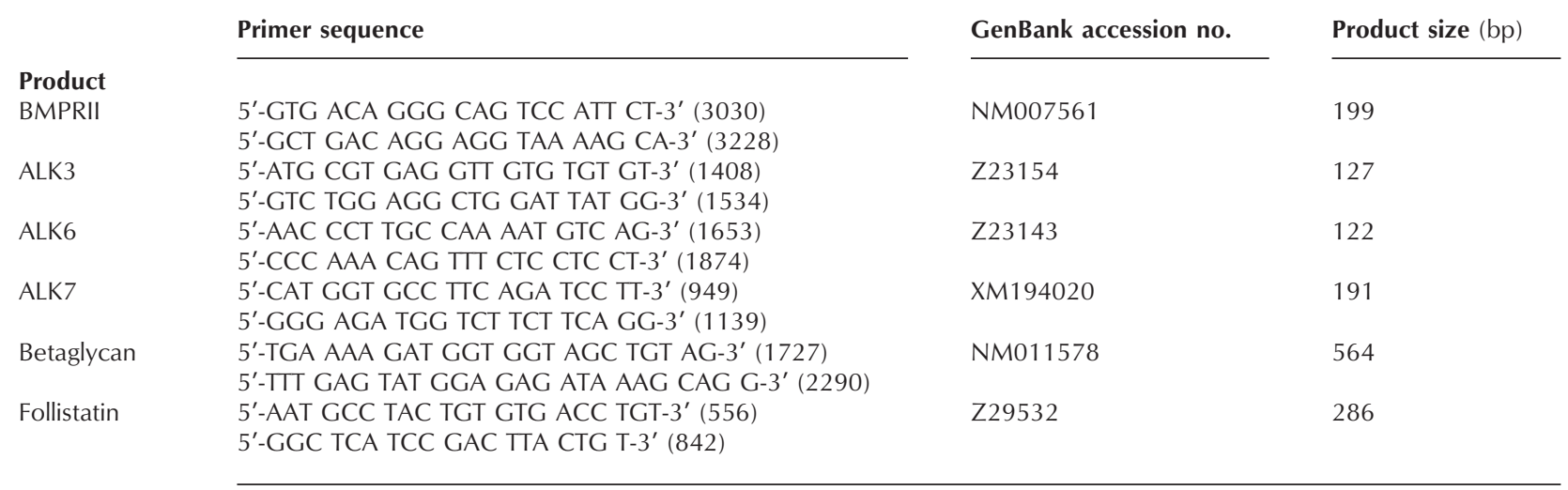

labelling reaction, the cDNA probes were hybridised to a microarray, incubated overnight at $60{ }^{\circ} \mathrm{C}$, then the quantitative intensities of radioactivity on the washed membrane were determined using a phosphorimager (Storm; Amersham Biosciences), and analysed using GEArray Analyzer software (version 1.0; SuperArray Inc.).

Individual binding protein and receptor mRNA species expressed by AC cells were analysed by real-time RTPCR assays. For each RT-PCR reaction, a 1 or $2 \mu \mathrm{g}$ aliquot of total RNA was reverse transcribed with $50 \mathrm{U}$ of expand reverse transcriptase in a volume of $20 \mu \mathrm{l}$ using $250 \mathrm{ng}$ oligo-dT primers. Primers and conditions for inhibin subunit, glyceraldehyde-3-phosphate dehydrogenase and activin receptor type I, IB, II and IIB amplifications were as previously described (Drummond et al. 2000, 2002). Primers and product sizes for other reactions are shown in Table 1. The identity of the sequence produced from AC cells by each primer set was confirmed by nucleotide sequencing.

Real-time PCR amplification assays were performed in a LightCycler (Roche Diagnostics Australasia) using FastStart DNA Master SYBR Green I, with $2 \mu \mathrm{l}$ cDNA sample and primer strands (each $0 \cdot 25 \mu \mathrm{M}$ ) in a final volume of $20 \mu \mathrm{l}$. For each analyte, denatured sample (pooled RNA from representative untreated AC cell cultures maintained in serum-free medium) and matching purified standard cDNA were subjected to 40 cycles of amplification and quantification (using the second derivative maximum method from the LightCycler Software 3.5.3; Roche Molecular Biochemicals), after which melting curves were assessed to establish amplification specificity.

\section{Inhibin secretion by $A C$ cells}

Monolayers of $2 \times 10^{6} \mathrm{AC}$ cells were incubated overnight in culture medium containing either $10 \% \mathrm{FBS}$ or $10 \% \mathrm{AS}$, conditioned media were collected, cell debris was removed by centrifugation, then inhibin $\mathrm{A}$ and inhibin $\mathrm{B}$ were determined by specific ELISAs (Groome et al. 1994, 1996) according to the manufacturer's instructions (Oxford Bio-Innovations, Oxfordshire, UK) against standards diluted in the respective matching unconditioned medium. For inhibin A, the standard was the World Health Organization human inhibin A standard \#91/624, the detection limit was $4 \mathrm{pg} / \mathrm{ml}$, and crossreaction with inhibin $\mathrm{B}$ is below $0.1 \%$ (Groome et al. 2001). For inhibin B, the standard was an 'in-house' rat ovarian extract, as previously described (Drummond et al. 2000), the detection limit equates to $7 \mathrm{pg} / \mathrm{ml}$ of the World Health Organization human inhibin B standard \#96/784, and cross-reaction with inhibin A is approximately $0.5 \%$ (Groome et al. 1996).

\section{Data analysis}

All data and statistical analyses were performed using GraphPad Prism (version 3.00 for Windows; GraphPad Software Inc, San Diego, CA, USA). Tabulated data are presented as mean \pm S.E.M of results from replicated independent experiments. The extent of replication is indicated in the text, figure legends and tables. Results from multiple treatment groups were compared by one-way ANOVA, followed by post-hoc Neuman-Keuls multiple comparison test. $P<0.05$ was considered indicative of a significant difference.

\section{Results}

Expression of inhibin subunits and binding proteins by AC cells

The first aim of this study was to determine whether inhibins and their known binding proteins are produced by the mouse AC cell line. Expression of inhibin $\alpha, \beta_{\mathrm{A}}$ and $\beta_{\mathrm{B}}$ subunits was demonstrated by RT-PCR (Fig. $1 \mathrm{a}$ ). 
(a)

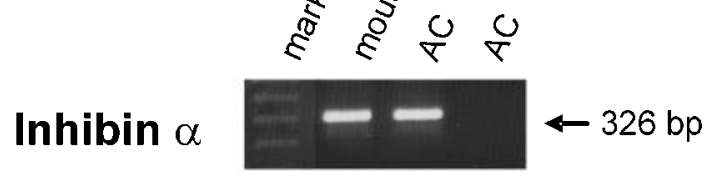

Inhibin $\beta$ A

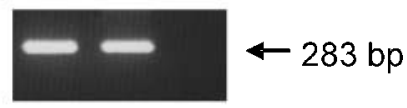

Inhibin $\beta B$

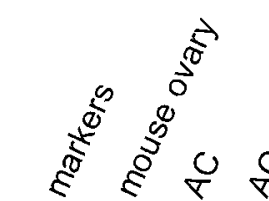

Betaglycan (b)
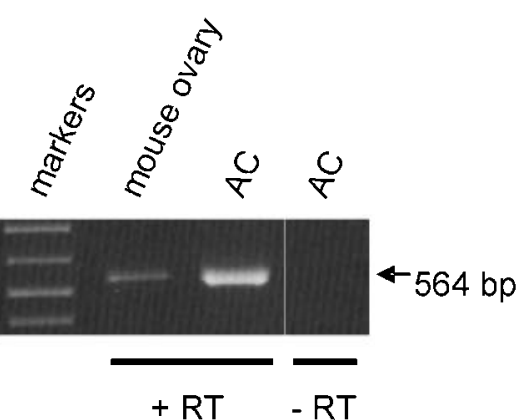

(d)

Follistatin

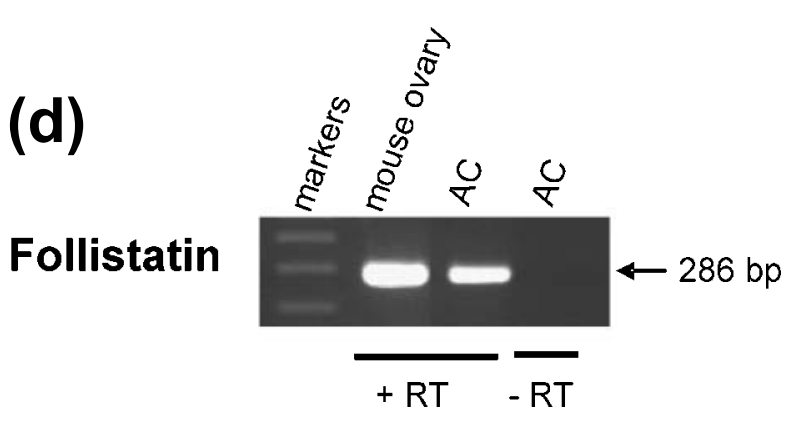

ActRIIB $\leftarrow-\leftarrow 302 \mathrm{bp}$

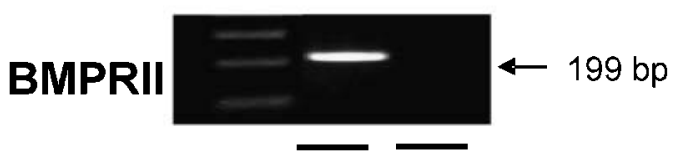

$+\mathrm{RT} \quad-\mathrm{RT}$

Figure 1 Expression of mRNA encoding (a) inhibin $\alpha, \beta_{\mathrm{A}}$ and $\beta_{\mathrm{B}}$ subunits, (b) betaglycan, (c) type II activin and BMP receptors, and (d) follistatin by mouse AC cells. In each case, RT-PCR was performed on total RNA extracted from AC cells cultured under serum-free conditions. Mouse ovarian cDNA was included as a positive control. Molecular weight markers were run in the first lane of each panel. +RT and -RT signify amplification yields after the inclusion and omission of reverse transcriptase, respectively.

ELISAs performed on medium collected from AC cell cultures showed that the cells secreted inhibin A, reaching a final concentration of $90 \mathrm{pg} / \mathrm{ml}$ in the culture medium, whereas inhibin B secretion was low but detectable (i.e. approximately $20 \mathrm{pg} / \mathrm{ml}$ ). These data show that each inhibin subunit mRNA was translated into protein, albeit at low levels.

Inhibins are known to interact with the transmembrane proteoglycan, betaglycan, type II receptors for activin and $\mathrm{BMP}$, and the secreted activin-binding protein, follistatin. AC cells expressed mRNA encoding betaglycan (Fig. 1b; 0.6 fg per $\mu \mathrm{g}$ total RNA), activin receptors type II and IIB (Fig. 1c; ActRII and ActRIIB expressed at 3 and
$50 \mathrm{fg}$ per $\mu \mathrm{g}$ total RNA, respectively), and the BMP type II receptor (Fig. 1c; BMPRII expressed at $8 \mathrm{fg}$ per $\mu \mathrm{g}$ total RNA), as determined by quantitative real-time PCR analyses. Thus, the AC cells have the capacity to make the complement of binding proteins that subserve the anti-activin and anti-BMP actions of inhibin. The cells also expressed follistatin mRNA (Fig. 1d; 20 fg per $\mu$ g total RNA).

AC cell expression of activins, BMPs, and their signalling components

cDNA membrane array analyses indicated that AC cells, in addition to expressing inhibin $\alpha$ and $\beta_{\mathrm{A}}$ subunits (Fig. 2a: 


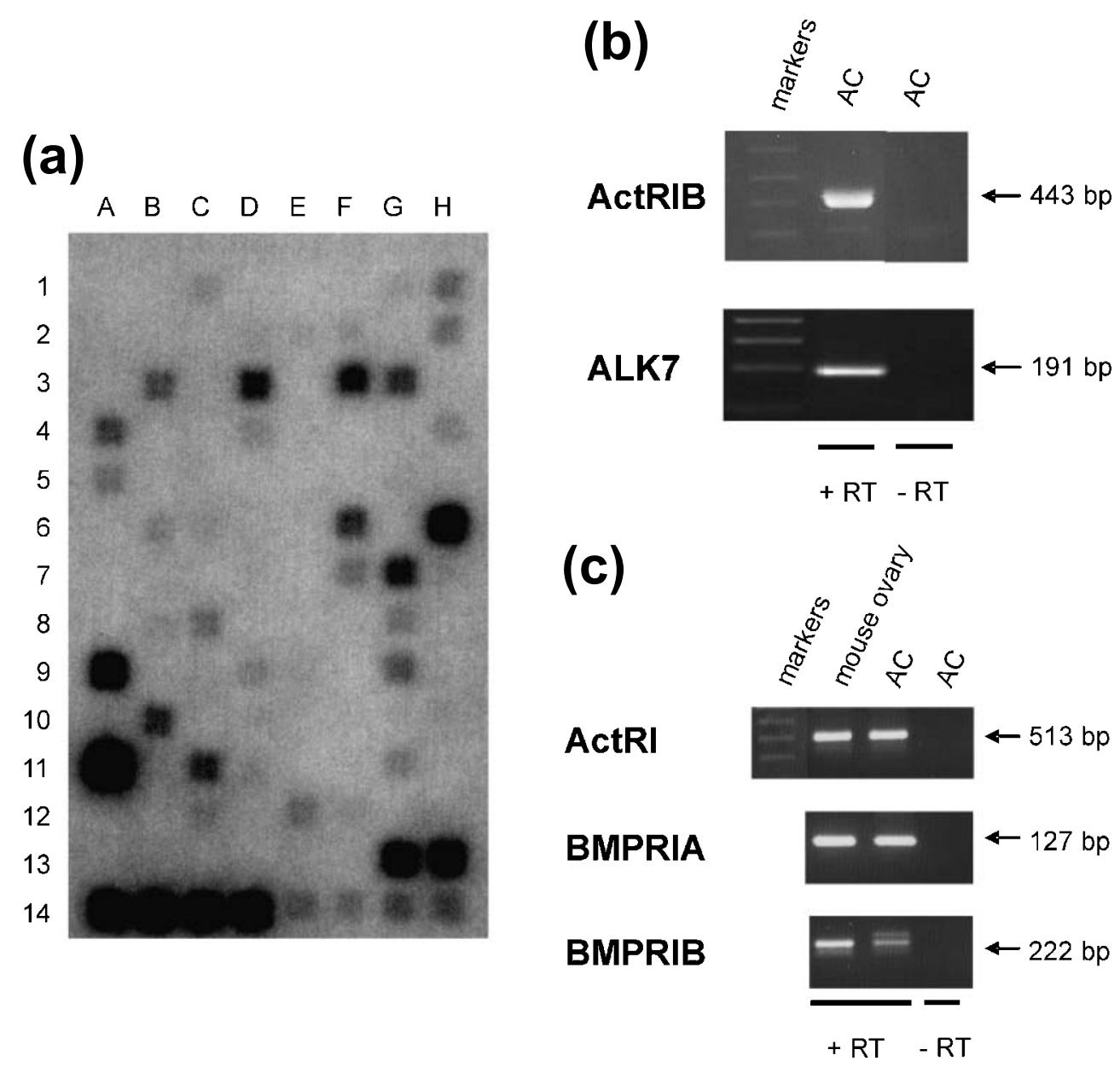

Figure 2 AC cell expression of mRNA encoding (a) TGF- $\beta$ superfamily ligands, signalling receptors, and downstream signalling partners assessed by CDNA array, and of type I receptors for (b) activin and (c) BMP assessed by RT-PCR. Each assay was performed on total RNA extracted from AC cells cultured under serum-free conditions. AC cell products mentioned in the text can be located in the array using the 14 numeral $\times 8$ letter grid shown in (a), in which $13 \mathrm{~A}-13 \mathrm{~F}$ are negative controls, and $13 \mathrm{G}, 13 \mathrm{H}$, and $14 \mathrm{~A}-14 \mathrm{H}$ are positive controls. Additional species expressed by AC cells but not described in the text were osteocalcin $(1 \mathrm{H})$, cdc25a (3G), cyclin-dependent kinase inhibitor p15 INK4b (4A), distal-less homeobox 2 $(4 \mathrm{H})$, inhibitor of DNA binding $2(6 \mathrm{H})$, integrin b5 (8C), Jun-B (8G), Runx1, (10H), Runx2/Osf2/Cbfa1 (11A), PAI-1 (11C), and TSC2 (11G). Molecular weight markers were run in the first lane of (b) and (c), in which +RT and - RT signify amplification yields after the inclusion and omission of reverse transcriptase, respectively. In (c), mouse ovarian cDNA was included as a positive control.

$7 \mathrm{~F}$ and $7 \mathrm{G}$, respectively), also expressed mRNA for the inhibin $\beta_{\mathrm{E}}$ subunit (Fig. 2a: 8B), BMP-2, -3, -4, -6 and $-8 \mathrm{a}$ (Fig. 2a: 2D, 2E, 2F, 2H and 3B, respectively), along with growth/differentiation factor (GDF) $-1,-3,-5$ and -9 (Fig. 2a: $5 \mathrm{G}, 6 \mathrm{~B}, 6 \mathrm{C}$ and 6F, respectively), and Lefty A and $\mathrm{B}$ (Fig. 2a: $5 \mathrm{~A}$ and $9 \mathrm{~A}$, respectively). In addition to betaglycan (Fig. 2a: 12E), expression of mRNA for activin receptor type II (ActRII; Fig. 2a: $1 \mathrm{C})$, TGF- $\beta$ receptor type I (ALK5; Fig. 2a: 12C), BMPRIA (ALK3) and BMPRII (Fig. 2a: 3D and 3F, respectively), BMP and activin membrane-bound inhibitor (BAMBI/nma; Fig. 2a: $1 \mathrm{G})$, and BMP binding proteins gremlin, Dan and noggin (Fig. 2a: 4D, 10B and 10D, respectively), were also evident, as was the expression of some other signalling components of the activin/TGF- $\beta$ and BMP pathways (Smads 2 and 6; Fig. 2a: 9D and 9G, respectively). Smads 1,3, 5 and 7 (Fig. 2a: 9C, 9E, 9F and 9H, respectively), TGF- $\beta$ type II receptor (Fig. $2 \mathrm{a}$ : $12 \mathrm{D}$ ), and other type I receptors for activin and BMP (ALK2, ALK4, ALK6) (Fig. 2a: 1A, 1B, and 3E, respectively) were below the threshold for detection in this assay.

RT-PCR analyses showed that AC cells expressed mRNA for the activin receptor type I (ActRIB/ALK4) and the alternate activin $\mathrm{B}$ signalling receptor, ALK7 
(Fig. 2b; expressed at 0.5 and 0.03 fg per $\mu$ g total RNA, respectively), along with BMP signalling receptors ActRI (ALK2) and BMPRIB (ALK6) (Fig. 2c; expressed at 20 and 1 fg per $\mu \mathrm{g}$ total RNA, respectively). RT-PCR analysis also confirmed the presence of mRNA for BMPRIA (Fig. 2c; expressed at 8 fg per $\mu$ g total RNA).

\section{Binding of $\left[{ }^{125}\right.$ I]inhibin to the mouse AC cell line}

Binding of $\left[{ }^{125} \mathrm{I}\right]$ inhibin $\mathrm{A}$ to $\mathrm{AC}$ cells was routinely conducted at $25{ }^{\circ} \mathrm{C}$ for $4 \mathrm{~h}$. Unlabelled inhibin A dosedependently competed for a maximum of $80 \%$ of total $\left[{ }^{125} \mathrm{I}\right]$ inhibin A binding to AC cells (i.e. non-specific binding averaged $20 \%$ of total) with an $\mathrm{IC}_{50}$ of $0.13 \mathrm{nM}$ (Fig. 3a; Table 2). Saturation binding studies (Fig. 3b) and Scatchard analyses (e.g. Fig. 3b inset) of inhibin A binding to AC cells revealed binding sites of high affinity $\left(\mathrm{K}_{\mathrm{d}}(1)=0.15 \mathrm{nM} ; 4300\right.$ sites/cell $)$ and low affinity $\left(K_{d}(2)=1.3 \mathrm{nM} ; 17000\right.$ sites/cell; also see Table 3). An additional large population of very low affinity sites $\left(\mathrm{K}_{\mathrm{d}}(3)\right.$ above $5 \mathrm{nM}$; more than 50000 sites/cell) could also be discriminated (e.g. Fig. 3b inset).

Inhibin $\mathrm{B}$ competed over a wide concentration range $(0 \cdot 01-50 \mathrm{nM})$ for all of the specific $\left[{ }^{125} \mathrm{I}\right]$ inhibin A binding to $\mathrm{AC}$ cells with an estimated $\mathrm{IC}_{50}$ of $1.7 \mathrm{nM}$ (Table 2; Fig. 3a). However, the competition curve was complex, and could be resolved into several phases separated by inflexion points, suggesting inhibin $B$ interacts with inhibin A binding sites of greatly different affinities (between 0.4 and $30 \mathrm{nM}$ ). The maximum cross-reaction of inhibin $\mathrm{B}$ with inhibin A binding sites averaged $<8 \%$.

Neither activin A nor activin B provided significant competition for $\left[{ }^{125} \mathrm{I}\right]$ inhibin A binding to AC cells (Table 2; Farnworth et al. 2001). In contrast, BMP-2, -6 and -7 competed for $21-33 \%$ of specific inhibin A binding to AC cells, with similar potencies $\left(\mathrm{IC}_{50}\right.$ values of $0 \cdot 2-$ 0.3 nM; Fig. 3c, Table 2).

\section{Binding of $\left[{ }^{125} I\right]$ inhibin to rat adrenal cells}

Binding of inhibin was examined in sections of rat adrenal tissue. $\left[{ }^{125}\right.$ I] inhibin A bound to cells of the adrenal cortex, but not the medulla, in adult male rat adrenal tissue (Fig. 4a), and this binding was competed by unlabelled inhibin $\mathrm{A}(20 \mathrm{nM})$ (Fig. $4 \mathrm{~b})$, consistent with the binding of $\left[{ }^{125} \mathrm{I}\right]$ inhibin $\mathrm{A}$ by the AC cell line. The most intense labelling occurred in the inner cortical zone, corresponding to the zona reticularis (Fig. 4a).

Binding of inhibin was then examined in primary cultures of adrenal cells. Monolayer cultures of cells prepared from whole adult rat adrenals bound substantial amounts of radiolabelled inhibin A, like the AC cell line, and unlabelled inhibin A dose-dependently blocked $61 \%$ of total binding (Fig. 5a) with an $\mathrm{IC}_{50}$ of $0 \cdot 11 \mathrm{nM}$ (Table 2), but inhibin A binding was insensitive to competition by activin A (Fig. 5a; Table 2). Similar results were obtained with adrenal cells obtained from adult female rats (data not shown).

Saturation binding studies (Fig. 5b) and Scatchard analyses (e.g. Fig. 5c) of inhibin A binding to primary adrenal cell cultures at $25^{\circ} \mathrm{C}$ revealed sites of both high affinity $\left(\mathrm{K}_{\mathrm{d}}(1)=0 \cdot 18 \mathrm{nM} ; 710\right.$ sites/cell) and low affinity $\left(\mathrm{K}_{\mathrm{d}}(2)=2.6 \mathrm{nM} ; 2500\right.$ sites/cell; also see Table 3). The pattern of high and low affinity sites was comparable to that seen in the mouse AC cells, but with fewer of each type of site per cell.

\section{$\left[{ }^{125} I\right]$ inhibin $A$ affinity labelling of AC cell binding proteins, including betaglycan}

$\left[{ }^{125} \mathrm{I}\right]$ inhibin A was crosslinked to cell surface proteins of $\mathrm{AC}$ cells using the bifunctional crosslinking agent, $\mathrm{BS}^{3}$. The affinity labelled protein complexes in whole cell lysate samples were separated by $7 \cdot 5 \%$ non-reducing SDS-PAGE. At least nine affinity labelled complexes of 50, 62, 74-80, 95, 105, 118, 145-148 and >220 kDa, respectively, (and two additional, poorly resolved smaller species) were detected by autoradiography (Fig. 6a). Each complex is assumed to include a contribution of approximately $30 \mathrm{kDa}$ from the iodinated inhibin. Complexes migrating at 50 and $90 \mathrm{kDa}$ were observed in the tracer alone (e.g. Fig. 6b, left lane), and presumably represent covalently-linked aggregates of inhibin molecules. Thus, the $50 \mathrm{kDa}$ complex extracted from affinity labelled AC cells may include, or consist entirely of, covalently-linked pairs of inhibin molecules. The 145-148 and >220 kDa complexes were the most intensely labelled, while the complex migrating at $118 \mathrm{kDa}$ varied greatly in its labelling intensity between experiments. $\left[{ }^{125} \mathrm{I}\right]$ inhibin A affinity labelling of all nine protein species on AC cells was abolished by the addition of excess unlabelled inhibin $\mathrm{A}$ (20 nM), but not activin A $(20 \mathrm{nM})$ (Fig. 6a). Exogenous follistatin-288 (20 nM) selectively intensified the band migrating at $62 \mathrm{kDa}$, with little change in the labelling intensity for other species (Fig. 6a).

Protein complexes extracted in whole cell lysates of AC cells after their affinity labelling with $\left[{ }^{125}\right.$ I] inhibin A were subjected to immunoprecipitation with antibodies directed against human betaglycan. Only the complexes of $>220 \mathrm{kDa}$ were identified by the antiserum (Fig. 6b, right lane). This species is consistent in size with glycosylated betaglycan (Lewis et al. 2000).

Detergent extracts prepared from AC cell membrane preparations after their affinity labelling with $\left[{ }^{125} \mathrm{I}\right]$ inhibin A displayed the same complement of complexes as were seen in whole cell lysates (Fig. 6c, left lane), confirming the association of all these binding proteins with the AC cell membrane. As with the whole cell lysates, only complexes of $>220 \mathrm{kDa}$ were immunoprecipitated from the membrane protein pool by anti-betaglycan serum (Fig. 6c, right lane). 


\section{(a)}

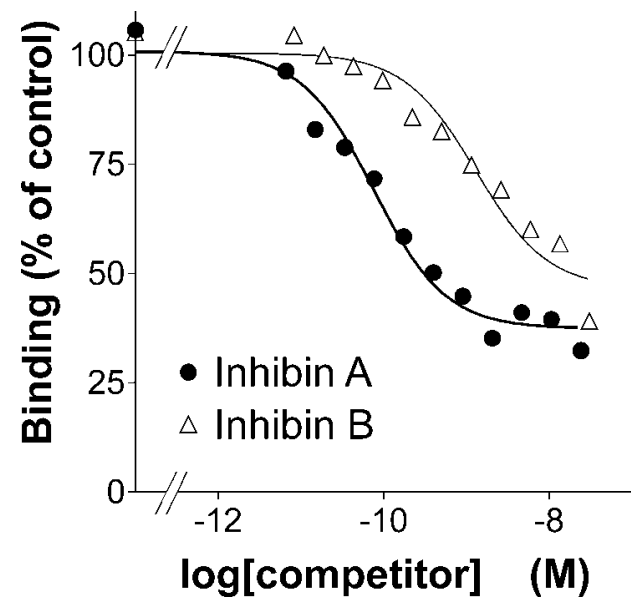

(c)

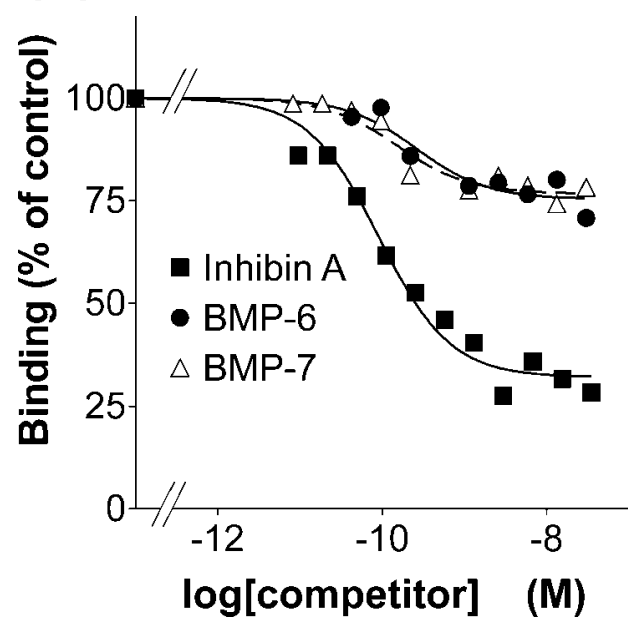

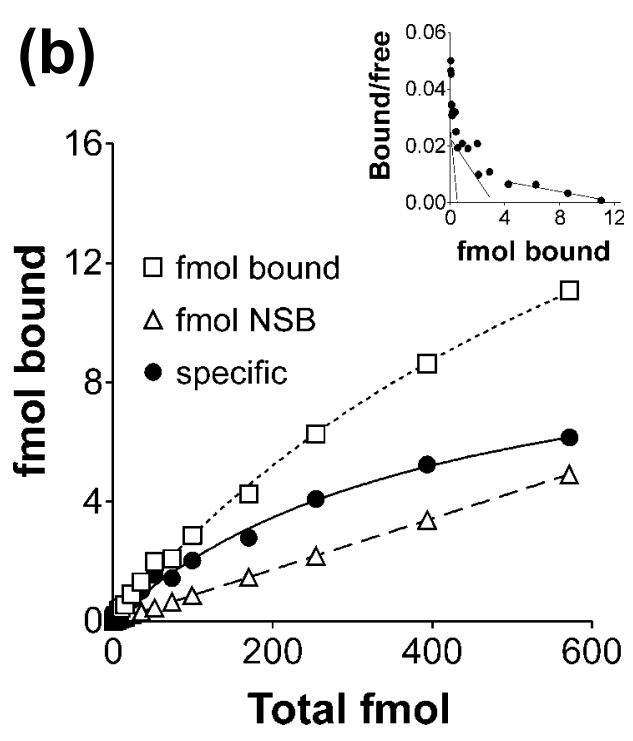

Figure 3 Binding of $\left[{ }^{125} \mathrm{I}\right]$ inhibin A to mouse AC cells. In all cases, binding was conducted at $25{ }^{\circ} \mathrm{C}$ with $0 \cdot 2 \times 10^{6}$ cells/well in $0 \cdot 125 \mathrm{ml}$ assay buffer. (a) A comparison of the competition provided by increasing concentrations of unlabelled inhibin A or inhibin B $(0 \cdot 03-20 \mathrm{nM})$ for the binding of $\left[{ }^{125}\right.$ I]inhibin A. Specific binding represented $10 \cdot 6 \%$, and non-displaceable binding was $2 \cdot 6 \%$, of input radioactivity. (b) A saturation curve analysis for the high affinity binding of $\left[{ }^{125} \mathrm{I}\right]$ inhibin $\mathrm{A}$ to $\mathrm{AC}$ cell monolayers. AC cells were incubated with increasing concentrations of $\left[{ }^{125} I\right]$ inhibin $A$ in the absence (total binding; $\square$ ) and presence (non-specific binding; $\triangle$ ) of excess unlabelled inhibin A, from which the difference (specific binding;

- was determined. In this experiment, non-linear regression analysis of the specific binding data identified sites of both high affinity $\left[K_{d}(\right.$ high $)=0.07 n M ; 1600$ sites/cell] and low affinity $\left[K_{d}(l o w)=3 n M ; 48000\right.$ sites/cell]. The inset shows a Scatchard analysis of inhibin binding data, from which three sites were deduced, as follows: $\mathrm{K}_{\mathrm{d}}(1)=0.10 \mathrm{nM}$, with 2000 sites/cell; $\mathrm{K}_{\mathrm{d}}(2)=0 \cdot 70 \mathrm{nM}$, with 13000 sites/cell; $\mathrm{K}_{\mathrm{d}}(3)=5.6 \mathrm{nM}$, with 50000 sites/cell. (c) A comparison of the competition provided by increasing concentrations of unlabelled inhibin A, BMP-6 or BMP-7 for the binding of $\left[{ }^{125}\right.$ I] inhibin A to AC cells. The data presented in each panel are from single representative experiments, and aggregate data are summarised in Table 2 ( $\mathrm{a}$ and $\mathrm{c}$ ) and Table 3 (b).

Separate monolayers of AC cells were incubated with $\left[{ }^{125} \mathrm{I}\right]$ inhibin $\mathrm{A}$ and progressively increasing concentrations of unlabelled inhibin A $(0 \cdot 08-5 \mathrm{nM})$, the affinity labelled protein complexes were separated by $7 \cdot 5 \%$ non-reducing SDS-PAGE (Fig. 7a), then the labelling intensity for individual protein complexes was titrated using densitometric analysis of the resulting autoradiographs. Each complex displayed a sensitivity to competition from 
Table 2 Inhibition of $\left[{ }^{125} \mathrm{I}\right]$ inhibin $\mathrm{A}$ binding to $\mathrm{AC}$ and male rat adrenal cells provided by TGF- $\beta$ superfamily members through direct competition during $4 \mathrm{~h}$ at $25{ }^{\circ} \mathrm{C}$

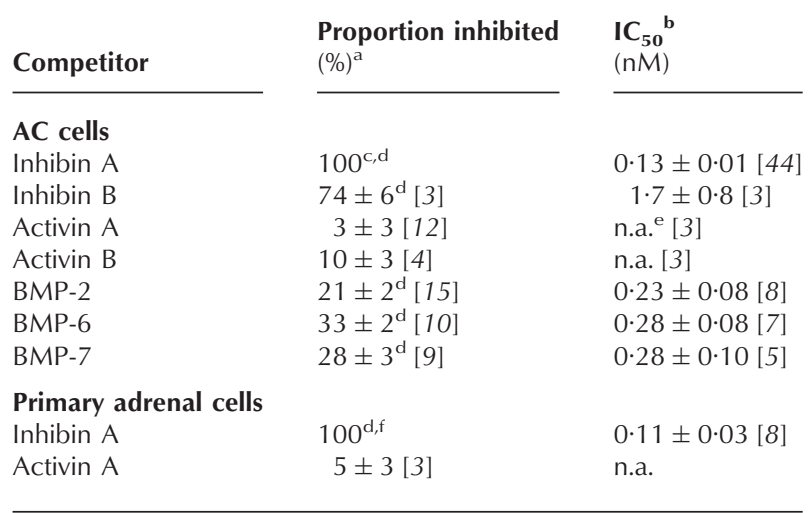

Results are mean \pm S.E.M. of $[n]$ replicate experiments.

aproportion of specific binding was determined after correction of data for non-specific inhibin binding; ${ }^{b} \mathrm{IC}_{50}=$ median inhibitory concentration; ${ }^{c}$ total binding ranged between 4 and $15 \%$ of total input counts, and non-specific binding ranged between 1 and $4 \%$; ${ }^{\mathrm{d}} P<0.05$; ${ }^{\mathrm{e}}$ n.a., not assessable; ${ }^{\mathrm{f}}$ total binding averaged $3.9 \%$ of total input counts, and non-specific binding averaged $1 \cdot 4 \%$.

unlabelled inhibin A that was similar to the sensitivity determined for total binding of $\left[{ }^{125} \mathrm{I}\right]$ inhibin $\mathrm{A}$ to the AC cell monolayers (Fig. 7b).

\section{$\left[{ }^{125}\right.$ I]inhibin $A$ affinity labelling of rat adrenal binding proteins}

Primary cultures of cells from adult male and female rat adrenal glands displayed a common pattern of affinity labelling with $\left[{ }^{125} \mathrm{I}\right]$ inhibin A (Fig. 8a), and this pattern qualitatively resembled that obtained in the mouse AC cells (Fig. 8b). However, compared with the levels of labelling in the cell line, the $95 \mathrm{kDa}$ complex was barely evident in the primary cultures, and the band at 145$148 \mathrm{kDa}$ was less prominent (Fig. 8, a \& b). Unlabelled (a)

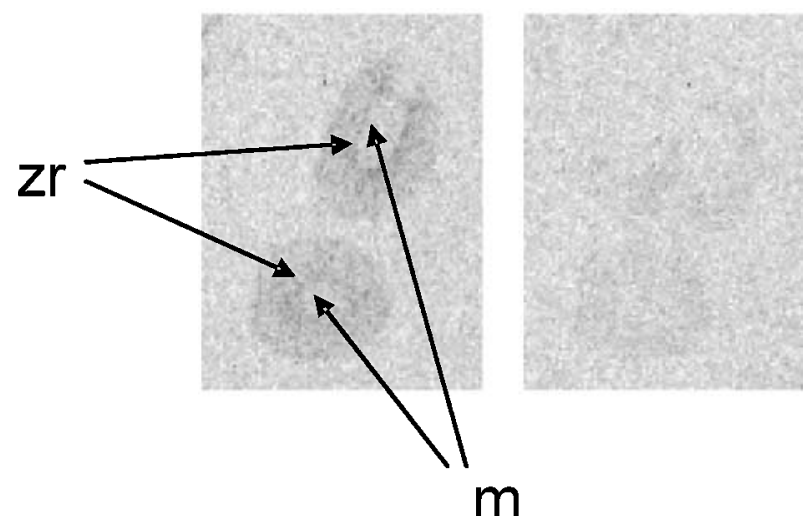

Figure 4 Specific binding of $\left[{ }^{125} \mathrm{I}\right]$ inhibin $\mathrm{A}$ to frozen sections of male rat adrenal gland. Binding of $\left[{ }^{125} \mathrm{I}\right]$ inhibin $\mathrm{A}$ to thawed sections was conducted at $37^{\circ} \mathrm{C}$ in the absence (a) and presence (b) of an excess of unlabelled inhibin (final concentration $20 \mathrm{nM}$ ). $\mathrm{m}$ indicates medulla, $\mathrm{zr}$ represents zona reticularis. The experiment was replicated, with similar results.

inhibin A prevented affinity labelling of rat adrenal cell proteins in a dose-dependent manner, unlike activin A (Fig. 8a). As with AC cells, affinity labelling of the $118 \mathrm{kDa}$ complex was inconsistently observed in primary adrenal cell cultures but, when evident, was prevented by excess unlabelled inhibin $\mathrm{A}$. When the binding of $\left[{ }^{125} \mathrm{I}\right]$ inhibin $\mathrm{A}$ to male rat adrenal cell cultures was terminated at various times between 0.5 and $4 \mathrm{~h}$ after addition of the tracer at $25^{\circ} \mathrm{C}$, and affinity labelled complexes were investigated by autoradiography, the labelling of the $35,40,50,74-80,105$ and $>220 \mathrm{kDa}$ complexes was already evident at the earliest time-point, and intensified with time (Fig. 8b). In contrast, the 118 and $145-148 \mathrm{kDa}$ complexes were barely evident at $0 \cdot 5 \mathrm{~h}$, but intensified from $1 \mathrm{~h}$ onward (Fig. 8b).

Table 3 Dissociation constants $\left(\mathrm{K}_{\mathrm{d}}\right)$ and binding site concentrations estimated by Scatchard analysis for the binding of $\left[{ }^{125}\right.$ I] inhibin $\mathrm{A}$ to mouse $\mathrm{AC}$ cells and primary cultures of adult male rat adrenal cells during $4 \mathrm{~h}$ incubation at $25^{\circ} \mathrm{C}$. Results are mean \pm S.E.M. of data from $n$ separate experiments

\begin{tabular}{|c|c|c|}
\hline & Inhibin A & \\
\hline & binding site 1 & binding site 2 \\
\hline $\begin{array}{l}\text { AC cells } \\
\mathrm{K}_{d}(\mathrm{nM}) \\
\text { Binding site concentration } \\
\text { (molecules/cell) }\end{array}$ & $\begin{array}{l}0 \cdot 15 \pm 0 \cdot 01[n=24] \\
4300 \pm 200\end{array}$ & $\begin{array}{c}1 \cdot 3 \pm 0 \cdot 1 \\
17000 \pm 1300\end{array}$ \\
\hline $\begin{array}{l}\text { Primary adrenal cells (male } \\
\mathrm{K}_{\mathrm{d}}(\mathrm{nM}) \\
\text { Binding site concentration } \\
\text { (molecules/cell) }\end{array}$ & $\begin{array}{l}0 \cdot 18 \pm 0 \cdot 03[n=8] \\
710 \pm 150\end{array}$ & $\begin{array}{r}2 \cdot 6 \pm 0 \cdot 6 \\
2500 \pm 600\end{array}$ \\
\hline
\end{tabular}


(a)

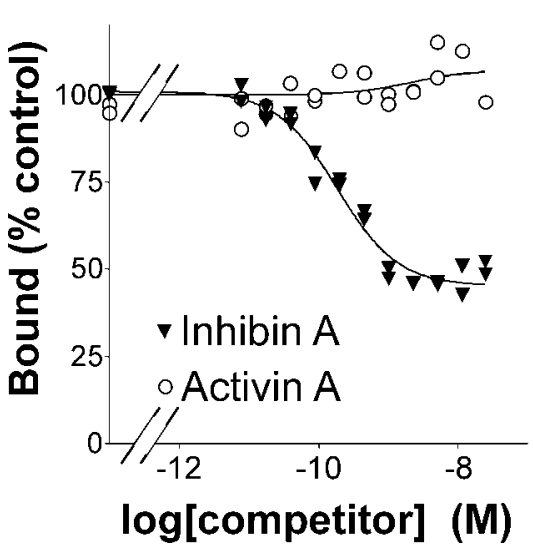

(b)

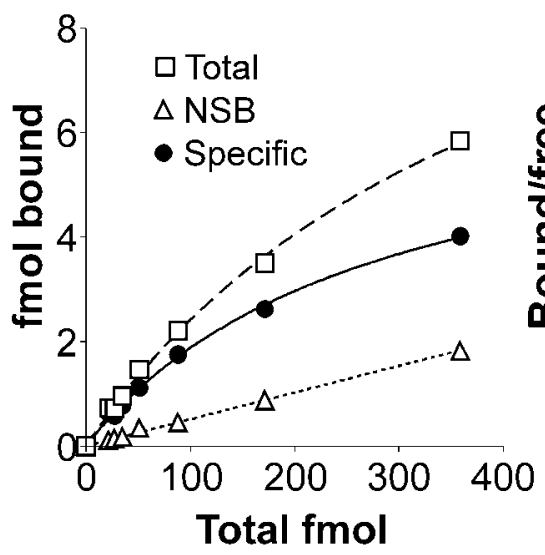

(c)

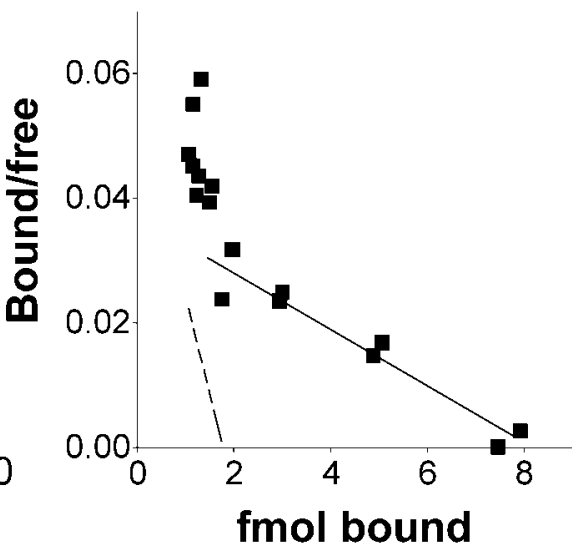

Figure 5 Binding of $\left[{ }^{125} \mathrm{I}\right]$ inhibin A to adult male rat adrenal cells in primary culture. In all cases, binding was conducted at $25{ }^{\circ} \mathrm{C}$ using $1 \times 10^{6}$ adult male rat adrenal cells/well in $0.375 \mathrm{ml}$ assay buffer. (a) A comparison of the competition provided by increasing concentrations of unlabelled inhibin A or activin A $(0.03-20 \mathrm{nM})$ in a single representative experiment. Specific binding averaged 3.9\%, and non-displaceable binding averaged $1 \cdot 4 \%$, of input radioactivity $(n=8)$. Aggregate data from replicate experiments are summarised in Table 2. (b) A saturation curve analysis of high affinity binding of $\left[{ }^{125}\right.$ I]inhibin A to primary adrenal cell monolayers. Cultures of cells were incubated with increasing concentrations of $\left[{ }^{125}\right.$ I] inhibin $A$ in the absence (total binding; $\square$ ) and presence (non-specific binding; $\triangle$ ) of excess unlabelled inhibin A, from which the difference (specific binding; - was determined. (c) A representative Scatchard plot of $\left.\left[{ }^{125}\right]\right]$ inhibin A binding to adult male rat adrenal cells in culture. The broken line represents binding to high affinity sites after correction for the low affinity component (full line), which was corrected for non-specific binding determined in the presence of $20 \mathrm{nM}$ unlabelled inhibin A. In this experiment, dissociation constants $\left(K_{d}\right.$, in $\left.n M\right)$ estimated from these data are as follows: $K_{d}(1)=0 \cdot 27, K_{d}(2)=2 \cdot 0$. The matching binding site concentrations (sites/cell) are as follows: at site $1=1600$; site $2=10400$. The data presented in (c) are representative of 8 independent trials, and aggregate data from multiple experiments are summarised in Table 3.

\section{Inhibin antagonism of activin $A$ binding in AC cells}

AC cell monolayers in crosslinking experiments bound low levels of $\left[{ }^{125} \mathrm{I}\right]$ activin $\mathrm{A}(1 \cdot 7 \%$ of total counts added). Excess unlabelled activin A $(20 \mathrm{nM})$ competed for an average $51 \pm 4 \%$ of total $\left[{ }^{125} \mathrm{I}\right]$ activin A binding (mean \pm S.E.M., $n=5$ )(i.e. non-specific binding of $\left[{ }^{125} \mathrm{I}\right]$ activin $\mathrm{A}$ averaged 49\%). Inhibin A (20 nM) competed for $38 \pm 6 \%$ (mean \pm S.E.M., $n=5$ ) of total activin A binding. Inhibition of activin A binding by both competitors was statistically significant $(P<0 \cdot 001)$.

\section{Discussion}

This study has established that mouse adrenocortical (AC) cells express inhibin subunits, secrete inhibins $A$ and $B$, bind radiolabelled inhibin $A$ via high and low affinity sites, and express mRNA encoding known inhibin binding proteins, including activin type II and IIB and BMP type II receptors, the inhibin/TGF- $\beta$ co-receptor, betaglycan, and follistatin. Inhibins therefore fulfil some of the requirements to be classed as autocrine factors for this cell line, since these transmembrane proteins can mediate inhibitory actions of inhibin against activins (and BMPs) in accordance with the current model of inhibin action (Lewis et al. 2000, Wiater \& Vale 2003).
By secreting inhibins, the AC cell line resembles the adrenal cortex and tumours arising from it, which strongly express the inhibin $\alpha$-subunit and weakly express both $\beta$-subunits (Crawford et al. 1987, Meunier et al. 1988, Voutilainen et al. 1991, Munro et al. 1999, Arola et al. 2000), and the human AC H295R cell line, which also makes and secretes activin $A$ and both inhibin $A$ and inhibin B (Vanttinen et al. 2002). The present results also show that AC cells express mRNA encoding several BMP/GDF ligands (BMP-2, -3, -4, -6 and -8a; GDF-1, $-3,-5$ and -9 ) and Lefty $A$ and $B$, for which autocrine roles in the adrenal cortex are yet to be identified. Nevertheless, such roles seem likely, because AC cells express mRNA encoding multiple activin and BMP receptors and their respective downstream signalling components, and respond to exogenous activin and BMP (Ooi et al. 2002).

Binding of radiolabelled inhibin A to mouse AC and rat primary adrenal cells shows common characteristics. Scatchard analyses reveal two classes of binding sites, $\mathrm{K}_{\mathrm{d}}(1)$ of $0 \cdot 15-0 \cdot 18 \mathrm{nM}$ and $\mathrm{K}_{\mathrm{d}}(2)$ of $1 \cdot 3-2 \cdot 6 \mathrm{nM}$, with $710-$ 4300 high affinity, and 2500-17 000 low affinity binding sites/cell. The concentrations and affinities estimated for these binding sites resemble those determined for the binding of inhibin A to Leydig (TM3) and Sertoli (TM4) cell lines (Harrison et al. 2001). An additional very low affinity $\left(\mathrm{K}_{\mathrm{d}}(3)>5 \mathrm{nM}\right)$ inhibin $\mathrm{A}$ binding site was 


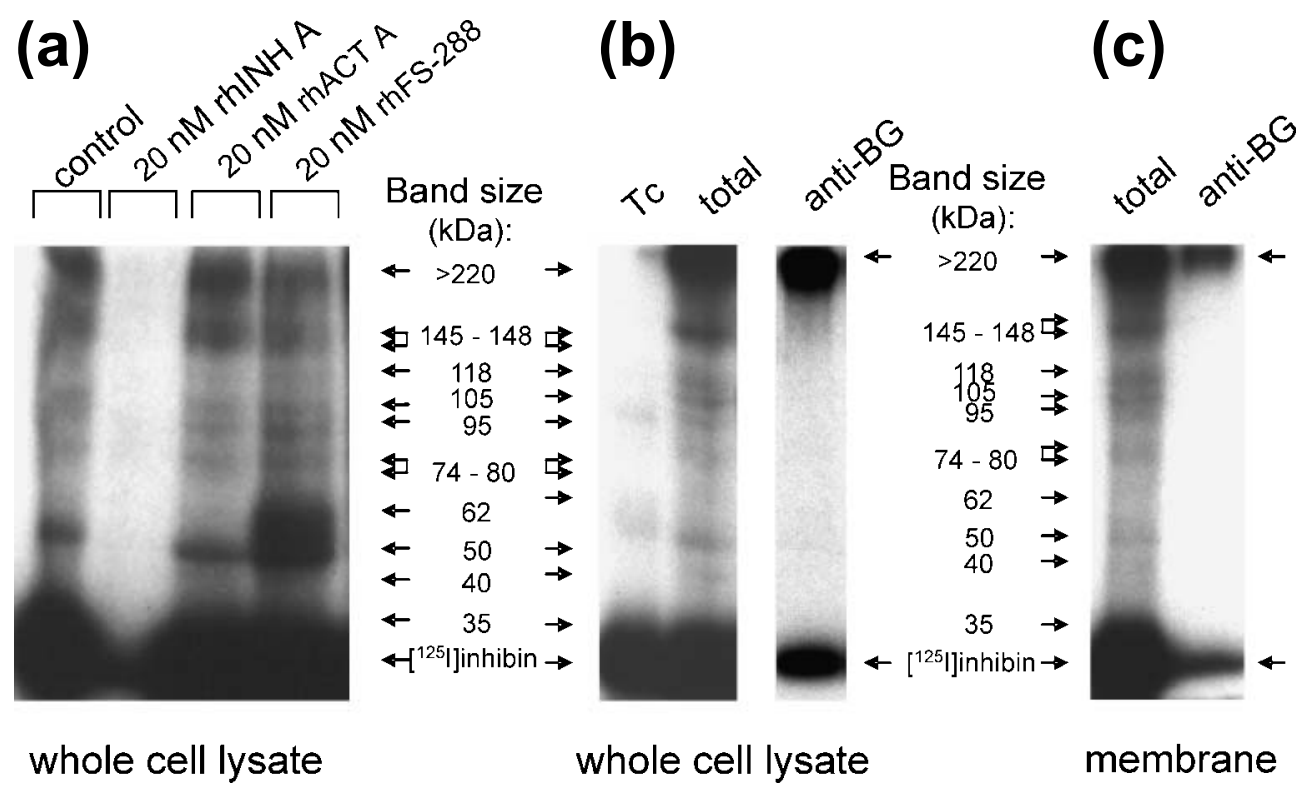

Figure 6 Affinity labelling of AC cell inhibin binding proteins. In each case, binding was conducted for $4 \mathrm{~h}$ at $25{ }^{\circ} \mathrm{C}$, $\left[{ }^{125} \mathrm{I}\right]$ inhibin A was crosslinked to its binding proteins using $\mathrm{BS}^{3}$, and extracted protein complexes were separated by $7 \cdot 5 \%$ non-reducing SDS-PAGE. (a) and (b) show labelled species in lysates of whole AC cells, and (c) shows labelled species in the lysate of an AC cell membrane preparation obtained by differential centrifugation of homogenised AC cells. The representative autoradiograph in panel a compares the $\left[{ }^{125} \mathrm{I}\right]$ inhibin $\mathrm{A}$ affinity labelled protein complexes obtained from AC cells that had been incubated in the absence of competitor (control), or presence of excess unlabelled inhibin A, activin A or follistatin-288 (each $20 \mathrm{nM}$ ). (b) and (c) provide comparisons of the distribution of $\left[{ }^{125} I\right]$ inhibin in the tracer alone (Tc), and in affinity labelled protein complexes before (total) and after immunoprecipitation (anti-BG) using antiserum directed against betaglycan. The sizes of each labelled complex indicated by arrows in (a)-(c) were deduced by comparison with marker proteins run in parallel.

also observed. The rat adrenal and AC cell binding sites show high specificity for inhibin A over activin A, and little crossreaction with activin B. They also crossreact only weakly with inhibin B, as previously seen with TM3 and TM4 cells (Harrison et al. 2001). Nevertheless, sufficient inhibin B blocks all of the specific binding of inhibin A to AC cells, with most of the competition occurring in two phases (apparent $\mathrm{IC}_{50}$ values of approximately 3 and $30 \mathrm{nM}$, respectively). The high affinity, capacity and specificity of the identified inhibin A binding sites suggest the AC cells may be targets for inhibin A from both adrenal (i.e. local) and endocrine sources.

Several lines of evidence suggest that inhibins and activins play significant roles in the adrenal gland. First, activin A inhibits mitogenesis while enhancing ACTHstimulated cortisol secretion in human adrenal fetal zone cells (Spencer et al. 1990, 1992). Secondly, both inhibin A and activin A increase the level of $\mathrm{P} 450 \mathrm{c} 17$ protein in H295R cells, although the mechanism by which inhibin mimics this activin action is not known (Wang et al. 2003). Thirdly, mice that cannot make inhibin $\alpha$-subunit, and hence are inhibin-deficient, rapidly develop gonadal tumours from which they die, whereas early removal of the gonads results in subsequent development of adrenal tumours, qualifying inhibin as an adrenal tumour suppressor (Matzuk et al. 1992, 1994), again by an unknown mechanism. A similar pattern of events occurs in transgenic mice that express SV-40 T-antigen under the control of a $6 \mathrm{~kb}$ portion of the inhibin $\alpha$-subunit promoter (Kananen et al. 1996). In the latter scenario, adrenal cell lines have been established from tumours that arose in the adrenal glands of gonadectomised mice (Kananen et al. 1996, Rahman et al. 2001), and the AC cell line is derived from one of these. While the AC cell line is believed to have arisen from the fetal X zone of the adrenal cortex (Kananen et al. 1996), the binding of inhibin A to adult rat adrenal cells suggests that inhibins have ongoing physiological roles in the adrenal cortex throughout development.

The substantial inhibin binding capacity of AC cells found here is consistent, in part, with an earlier study, in which mice that had been injected with $\left[{ }^{125}\right]$ inhibin A concentrated radiolabel in the adrenal glands. The tissue: blood ratio reached a peak of 3 one hour after tracer injection, and binding/accumulation of $\left[{ }^{125}\right]$ inhibin $\mathrm{A}$ was blocked by co-administration of excess unlabelled inhibin A (Woodruff et al. 1993). Although that study reported binding of $\left[{ }^{125}\right]$ inhibin $\mathrm{A}$ in both the adrenal medulla and 
(a) Inhibin A: $(\mathrm{nM})$

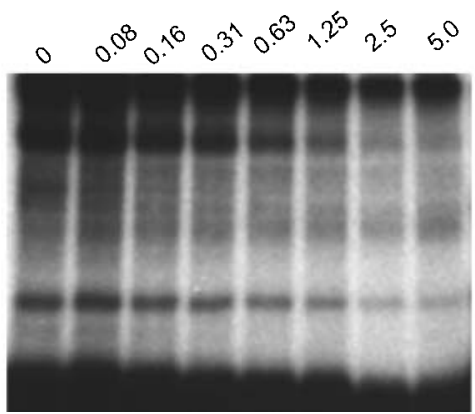

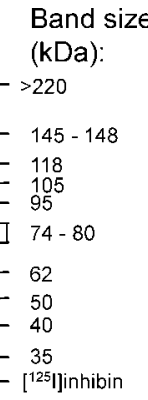

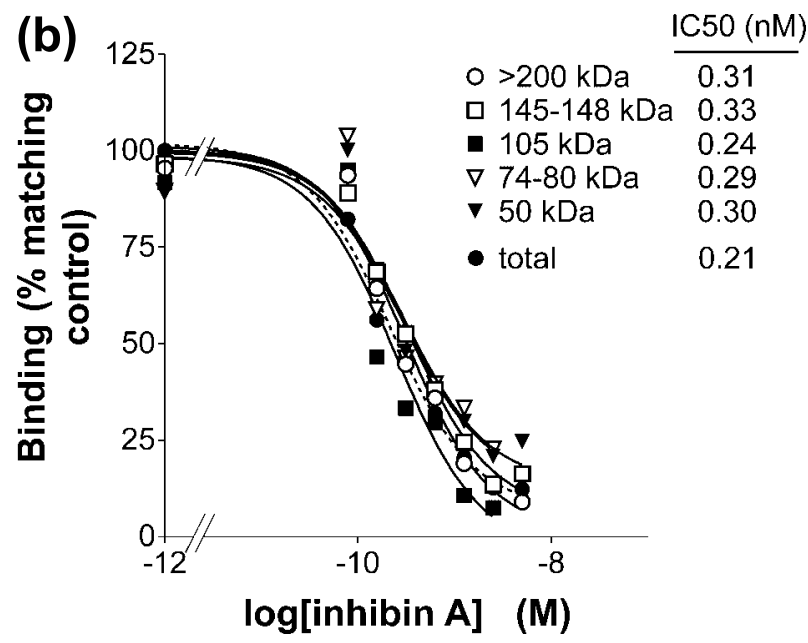

Figure 7 Comparison of competition from unlabelled inhibin A for $\left[{ }^{125}\right.$ I] inhibin A binding to whole AC cells in monolayer (total) and to individual affinity labelled protein complexes. (a) The distribution of radiolabel in complexes separated by $7 \cdot 5 \%$ non-reducing SDS-PAGE. For (b), the level of labelling of each complex (>220, $145-148,105,74-80$ and $50 \mathrm{kDa}$ ) was determined by densitometry from the autoradiograph shown in (a), and in each case was normalised against the labelling intensity in the control sample. The experiment was repeated once, with similar results.

cortex, we find that $\left[{ }^{125} \mathrm{I}\right]$ inhibin $\mathrm{A}$ binds specifically and almost exclusively to cells of the adrenal cortex, principally to those of the inner cortical zone.

Protein complexes of $35,40,50,62,74-80,105,118$, $145-148$ and $>220 \mathrm{kDa}$ are obtained from mouse AC and rat primary adrenal cells following their affinity labelling with $\left[{ }^{125}\right.$ I]inhibin A, which suggests that the AC cells provide a suitable model for inhibin A interactions with normal AC cells. A significant anomaly is the appearance of an additional $95 \mathrm{kDa}$ complex in AC cells. The affinity labelling of multiple membrane proteins with $\left[{ }^{125} \mathrm{I}\right]$ inhibin $A$ in AC cells provides a more complex pattern than that obtained from cells which overexpress betaglycan alongside type II receptors for activin or BMP. In those cases, only three complexes [175-250 kDa (glycosylated betaglycan), $110 \mathrm{kDa}$ (betaglycan core protein) and $75-85 \mathrm{kDa}$ (type II receptor)] have been reported (a)

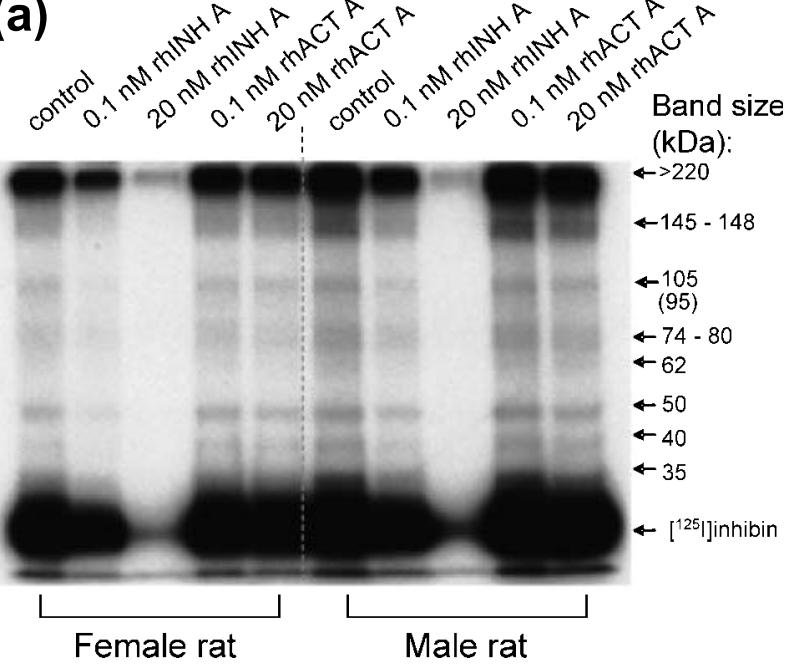

(b)

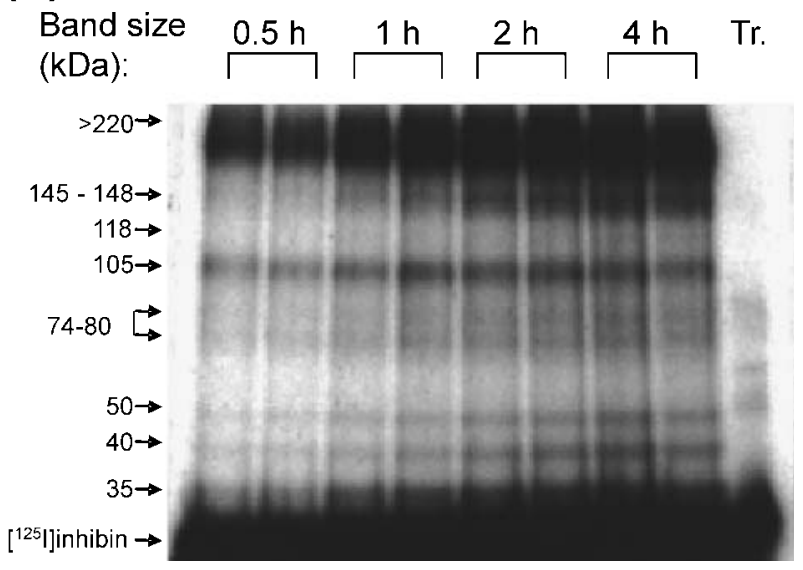

Figure 8 Affinity labelling of primary rat adrenal cell inhibin binding proteins with $\left[{ }^{125}\right.$ I]inhibin A. Each panel shows labelled species in cell lysates after their separation by $7 \cdot 5 \%$ non-reducing SDS-PAGE. Other details are as described in the legend to Fig. 6. The representative autoradiograph in panel a compares the $\left[{ }^{125}\right.$ I] inhibin affinity labelled protein complexes obtained from adult female and male rat adrenal cell monolayers that had been incubated in the absence of competitor (control), or presence of unlabelled inhibin A or activin A (each at 0.1 and $20 \mathrm{nM}$ ).

(b) shows the time-course for the $\left[{ }^{125} \mathrm{I}\right]$ inhibin affinity labelling of proteins from adult male rat primary adrenal cell cultures for periods between 0.5 and $4 \mathrm{~h}$. The sizes of each labelled complex indicated by arrows in each panel were deduced by comparison with marker proteins run in parallel.

(Lewis et al. 2000, Wiater \& Vale 2003). The AC cells express betaglycan mRNA, and $\left[{ }^{125} \mathrm{I}\right]$ inhibin A affinity labelled protein complexes of $>220 \mathrm{kDa}$ are immunoprecipitated with antibodies against betaglycan, in partial agreement with the earlier studies. However, the betaglycan antiserum does not recognise the $145-148 \mathrm{kDa}$ complex in AC cells, but recognises slightly smaller species, consistent in size with betaglycan core protein, in 
the TM3 and TM4 cell lines (P G Farnworth and Y Wang, unpublished observations). The 145-148 kDa complex in AC cells is therefore unlikely to be betaglycan core protein, and its identity is yet to be determined.

Inhibin A interacts with type II receptors for activin and BMP (Martens et al. 1997, Gray et al. 2000, Lewis et al. 2000, Chapman et al. 2002, Wiater \& Vale 2003), AC cells express mRNA for all three receptors, and appropriately sized protein complexes are affinity labelled with $\left[{ }^{125} \mathrm{I}\right]$ inhibin A on primary adrenal and AC cells. However, attempts to identify these complexes as native receptors for activin and/or BMP by immunoprecipitation were unsuccessful (P G Farnworth and Y Wang, unpublished observations), perhaps reflecting low levels of receptor expression under physiological conditions. Although the binding of $\left[{ }^{125} \mathrm{I}\right]$ inhibin A to rat adrenal and AC cells is unresponsive to competition from activin A (up to $50 \mathrm{nM}$ ), this finding agrees with results in other cell types, and probably reflects the increase in inhibin A affinity for activin type II receptors conferred by betaglycan (Lewis et al. 2000, Chapman et al. 2002) rather than a lack of involvement of such receptors in adrenal inhibin A binding. In contrast to the lack of competition provided by activins, picomolar concentrations of BMP-2, -6 and -7 compete for up to a third of specific inhibin A binding to AC cells, consistent with a role for BMP binding proteins in inhibin binding to AC cells.

A $62 \mathrm{kDa}$ protein complex that is faintly labelled with $\left[{ }^{125} \mathrm{I}\right]$ inhibin $\mathrm{A}$ in $\mathrm{AC}$ cells from both sources is greatly intensified in AC cells after exposure to follistatin-288, suggesting that inhibin interacts with endogenous follistatin to some extent under physiological circumstances. The intensity of affinity labelling of other inhibin binding species is little changed by exogenous follistatin-288. Thus, follistatin does not seem to promote inhibin binding, or to 'present' inhibin, to other proteins on the cell surface. On the other hand, inhibin A competes almost as effectively as activin A for $\left[{ }^{125} \mathrm{I}\right]$ activin A binding to AC cells, and affinity labelling studies provided evidence that inhibin A mainly displaces $\left[{ }^{125} \mathrm{I}\right]$ activin A from species consistent in size with follistatin, rather than activin receptors (P G Farnworth and $\mathrm{Y}$ Wang, unpublished observations).

In conclusion, the identification of inhibin A binding sites of high affinity and specificity, and characterization of multiple binding proteins on cells of the adrenal cortex raise questions about what physiological roles inhibins, locally produced and endocrine, might play in regulating adrenal functions. AC cell systems express betaglycan, and the type II receptors for activins and BMPs, which should provide for betaglycan-mediated blockade of activin/ BMP action by inhibin. Moreover, AC cells express multiple TGF- $\beta$ superfamily members, and requisite components of their signalling pathways, suggesting potential roles of activins and BMPs as autocrine factors. However, AC cells bind inhibin A via a number of proteins additional to those that mediate inhibin antagonism of activin and BMP action. As an extension of these studies, we are currently investigating whether inhibins affect adrenal cell functions, including steroidogenesis, either through antagonism of activin/BMP actions or by independent means.

\section{Acknowledgements}

The authors acknowledge the gifts of follistatin-288 provided by the NIDDK (NIDDK, NICHHD, USDA), and inhibin A, activin A and follistatin-288 provided by Biotech Australia (Sydney, Australia). We thank Peter Stanton for purifying activin A, Nafis Rahman and Ilpo Huhtaniemi for providing $\mathrm{C} \alpha-1$ cells, and Ann Drummond for establishing conditions for the inhibin subunit and activin receptor RT-PCR assays.

\section{Funding}

This study was funded by Program Grants (Reg Key Nos. 983212 \& 241000) and Fellowships for J K F (Reg Key No. 198705) and D M R (Reg Key No. 198708) from the National Health and Medical Research Council of Australia. The authors declare that there is no conflict of interest that would prejudice the impartiality of this scientific work.

\section{References}

Arola J, Liu J, Heikkila P, Ilvesmaki V, Salmenkivi K, Voutilainen R \& Kahri AI 2000 Expression of inhibin alpha in adrenocortical tumours reflects the hormonal status of the neoplasm. Journal of Endocrinology 165 223-229.

Beuschlein F, Looyenga BD, Bleasdale SE, Mutch C, Bavers DL, Parlow AF, Nilson JH \& Hammer GD 2003 Activin induces $\mathrm{x}$-zone apoptosis that inhibits luteinizing hormone-dependent adrenocortical tumor formation in inhibin-deficient mice. Molecular and Cellular Biology 23 3951-3964.

Buzzard JJ, Farnworth PG, De Kretser DM, O'Connor AE, Wreford NG \& Morrison JR 2003 Proliferative phase sertoli cells display a developmentally regulated response to activin in vitro. Endocrinology 144 474-483.

Chang H, Brown CW \& Matzuk MM 2002 Genetic analysis of the mammalian transforming growth factor-beta superfamily. Endocrine Reviews 23 787-823.

Chapman SC, Bernard DJ, Jelen J \& Woodruff TK 2002 Properties of inhibin binding to betaglycan, InhBP/p120 and the activin type II receptors. Molecular and Cellular Endocrinology 196 79-93.

Cocolakis E, Lemay S, Ali S \& Lebrun JJ 2001 The p38 MAPK pathway is required for cell growth inhibition of human breast cancer cells in response to activin. Journal of Biological Chemistry 276 18430-18436.

Crawford RJ, Hammond VE, Evans BA, Coghlan JP, Haralambidis J, Hudson B, Penschow JD, Richards RI \& Tregear GW 1987 Alpha-inhibin gene expression occurs in the ovine adrenal cortex, and is regulated by adrenocorticotropin. Molecular Endocrinology $1699-706$. 
Drummond AE, Dyson M, Thean E, Groome NP, Robertson DM \& Findlay JK 2000 Temporal and hormonal regulation of inhibin protein and subunit mRNA expression by post-natal and immature rat ovaries. Journal of Endocrinology 166 339-354.

Drummond AE, Le MT, Ethier JF, Dyson M \& Findlay JK 2002 Expression and localization of activin receptors, Smads, and beta glycan to the postnatal rat ovary. Endocrinology 143 1423-1433.

Drummond AE, Findlay JK \& Ireland JJ 2004 Animal models of inhibin action. Seminars in Reproductive Medicine 22 243-252.

Dupont J, McNeilly J, Vaiman A, Canepa S, Combarnous Y \& Taragnat C 2003 Activin signaling pathways in ovine pituitary and LbetaT2 gonadotrope cells. Biology of Reproduction 68 1877-1887.

Farnworth PG, Robertson DM, de Kretser DM \& Burger HG 1988 Effects of 31 kilodalton bovine inhibin on follicle-stimulating hormone and luteinizing hormone in rat pituitary cells. in vitro: actions under basal conditions. Endocrinology 122 207-213.

Farnworth PG, Harrison CA, Leembruggen P, Chan KL, Stanton PG, Ooi GT, Rahman NA, Huhtaniemi IT, Findlay JK \& Robertson DM 2001 Inhibin binding sites and proteins in pituitary, gonadal, adrenal and bone cells. Molecular and Cellular Endocrinology $18063-71$.

Gray PC, Greenwald J, Blount AL, Kunitake KS, Donaldson CJ, Choe S \& Vale W 2000 Identification of a binding site on the type II activin receptor for activin and inhibin. Journal of Biological Chemistry 275 3206-3212.

Groome NP, Illingworth PJ, O'Brien M, Cooke I, Ganesan TS, Baird DT \& McNeilly AS 1994 Detection of dimeric inhibin throughout the human menstrual cycle by two-site enzyme immunoassay Clinical Endocrinology 40 717-723.

Groome NP, Illingworth PJ, O'Brien M, Pai R, Rodger FE, Mather JP \& McNeilly AS 1996 Measurement of dimeric inhibin B throughout the human menstrual cycle. Journal of Clinical Endocrinology and Metabolism 81 1401-1405.

Groome NP, Tsigou A, Cranfield M, Knight PG \& Robertson DM 2001 Enzyme immunoassays for inhibins, activins and follistatins Molecular and Cellular Endocrinology 180 73-77.

Harrison CA, Farnworth PG, Chan KL, Stanton PG, Ooi GT, Findlay JK \& Robertson DM 2001 Identification of specific inhibin A-binding proteins on mouse Leydig (TM3) and sertoli (TM4) cell lines. Endocrinology 142 1393-1402.

Hashimoto O, Kawasaki N, Tsuchida K, Shimasaki S, Hayakawa T \& Sugino H 2000 Difference between follistatin isoforms in the inhibition of activin signalling: activin neutralizing activity of follistatin isoforms is dependent on their affinity for activin Cell Signaling 12 565-571.

Hertan R, Farnworth PG, Fitzsimmons KL \& Robertson DM 1999 Identification of high affinity binding sites for inhibin on ovine pituitary cells in culture. Endocrinology 140 6-12.

Hsueh AJ, Dahl KD, Vaughan J, Tucker E, Rivier J, Bardin CW \& Vale W 1987 Heterodimers and homodimers of inhibin subunits have different paracrine action in the modulation of luteinizing hormone-stimulated androgen biosynthesis. PNAS 84 5082-5086.

Iemura S, Yamamoto TS, Takagi C, Uchiyama H, Natsume T, Shimasaki S, Sugino H \& Ueno N 1998 Direct binding of follistatin to a complex of bone-morphogenetic protein and its receptor inhibits ventral and epidermal cell fates in early Xenopus embryo. PNAS 95 9337-9342.

Kananen K, Markkula M, Mikola M, Rainio EM, McNeilly A \& Huhtaniemi I 1996 Gonadectomy permits adrenocortical tumorigenesis in mice transgenic for the mouse inhibin alpha-subunit promoter/simian virus $40 \mathrm{~T}$-antigen fusion gene: evidence for negative autoregulation of the inhibin alpha-subunit gene. Molecular Endocrinology 10 1667-1677.

Lewis KA, Gray PC, Blount AL, MacConell LA, Wiater E, Bilezikjian LM \& Vale W 2000 Betaglycan binds inhibin and can mediate functional antagonism of activin signalling. Nature 404 411-414.
Martens JW, de Winter JP, Timmerman MA, McLuskey A, van Schaik RH, Themmen AP \& de Jong FH 1997 Inhibin interferes with activin signaling at the level of the activin receptor complex in Chinese hamster ovary cells. Endocrinology 138 2928-2936.

Matzuk MM, Finegold MJ, Su JG, Hsueh AJ \& Bradley A 1992 Alpha-inhibin is a tumour-suppressor gene with gonadal specificity in mice. Nature $360313-319$.

Matzuk MM, Finegold MJ, Mather JP, Krummen L, Lu H \& Bradley A 1994 Development of cancer cachexia-like syndrome and adrenal tumors in inhibin-deficient mice. PNAS $918817-8821$.

Meunier H, Rivier C, Evans RM \& Vale W 1988 Gonadal and extragonadal expression of inhibin alpha, beta $\mathrm{A}$, and beta $\mathrm{B}$ subunits in various tissues predicts diverse functions. PNAS 85 247-251.

Munro LM, Kennedy A \& McNicol AM 1999 The expression of inhibin/activin subunits in the human adrenal cortex and its tumours. Journal of Endocrinology 161 341-347.

O'Connor AE \& De Kretser DM 2004 Inhibins in normal male physiology. Seminars in Reproductive Medicine 22 177-185.

Ooi GT, Escalona R, Wang Y. Leembruggen P, Ethier J-F, Findlay J \& Farnworth PG 2002 Regulation of P450c17 mRNA by TGF- $\beta$ superfamily members in a mouse adreanl cell line. Proceedings of the 45th Annual Scientific Meetings of the Endocrine Society of Australia 45 (abstract 147) 83.

Piek E, Heldin CH \& Ten Dijke P 1999 Specificity, diversity, and regulation in TGF-beta superfamily signaling. FASEB Journal 13 2105-2124.

Rahman NA, Kiiveri S, Siltanen S, Levallet J, Kero J, Lensu T, Wilson DB, Heikinheimo MT \& Huhtaniemi IT 2001 Adrenocortical tumorigenesis in transgenic mice: the role of luteinizing hormone receptor and transcription factors GATA-4 and GATA-61. Reproductive Biology 1 5-9.

Schneyer AL, Rzucidlo DA, Sluss PM \& Crowley WF Jr. 1994 Characterization of unique binding kinetics of follistatin and activin or inhibin in serum. Endocrinology 135 667-674.

Shimonaka M, Inouye S, Shimasaki S \& Ling N 1991 Follistatin binds to both activin and inhibin through the common subunit Endocrinology 128 3313-3315.

Spencer SJ, Rabinovici J \& Jaffe RB 1990 Human recombinant activin-A inhibits proliferation of human fetal adrenal cells in vitro Journal of Clinical Endocrinology and Metabolism 71 1678-1680.

Spencer SJ, Rabinovici J, Mesiano S, Goldsmith PC \& Jaffe RB 1992 Activin and inhibin in the human adrenal gland. Regulation and differential effects in fetal and adult cells. Journal of Clinical Investigation 90 142-149.

Spencer SJ, Mesiano S, Lee JY \& Jaffe RB 1999 Proliferation and apoptosis in the human adrenal cortex during the fetal and perinatal periods: implications for growth and remodeling. Journal of Clinical Endocrinology and Metabolism 84 1110-1115.

Sugino K, Kurosawa N, Nakamura T, Takio K, Shimasaki S, Ling N, Titani K \& Sugino H 1993 Molecular heterogeneity of follistatin, an activin-binding protein. Higher affinity of the carboxyl-terminal truncated forms for heparan sulfate proteoglycans on the ovarian granulosa cell. Journal of Biological Chemistry 268 15579-15587.

Suzuki J, Otsuka F, Inagaki K, Takeda M, Ogura T \& Makino H 2004 Novel action of activin and bone morphogenetic protein in regulating aldosterone production by human adrenocortical cells Endocrinology 145 639-649.

Vale W, Rivier C, Hsueh A, Campen C, Meunier H, Bicsak T, Vaughan J, Corrigan A, Bardin W, Sawchenko P et al. 1988 Chemical and biological characterization of the inhibin family of protein hormones. Recent Progress in Hormone Research 44 1-34.

Vanttinen T, Kuulasmaa T, Liu J \& Voutilainen R 2002 Expression of activin/inhibin receptor and binding protein genes and 
regulation of activin/inhibin peptide secretion in human adrenocortical cells. Journal of Clinical Endocrinology and Metabolism 87 4257-4263.

Voutilainen R, Eramaa M \& Ritvos O 1991 Hormonally regulated inhibin gene expression in human fetal and adult adrenals. Journal of Clinical Endocrinology and Metabolism 73 1026-1030.

Wang EY, Ma EY \& Woodruff TK 2003 Activin signal transduction in the fetal rat adrenal gland and in human H295R cells. Journal of Endocrinology 178 137-148.

Wiater E \& Vale W 2003 Inhibin is an antagonist of bone morphogenetic protein signaling. Journal of Biological Chemistry 278 7934-7941.
Woodruff TK, Krummen L, Chen SA, Lyon R, Hansen SE, DeGuzman G, Covello R, Mather J \& Cossum P 1993

Pharmacokinetic profile of recombinant human (rh) inhibin A and activin $\mathrm{A}$ in the immature rat. II. Tissue distribution of $\left[{ }^{125} \mathrm{I}\right] \mathrm{rh}$-inhibin $\mathrm{A}$ and $\left[{ }^{125} \mathrm{I}\right] \mathrm{rh}$-activin $\mathrm{A}$ in immature female and male rats. Endocrinology 132 725-734

Received 16 November 2005

Accepted 28 November 2005 